\title{
WAKAF UANG \\ DALAM PERSPEKTIF HUKUM ISLAM
}

\author{
Nanang Qosim*
}

\begin{abstract}
Waqf is a wakif legal act to separate and / or hand over some of his possessions to be used forever or for a certain period in accordance with his interests for the purposes of worship and / or general welfare according to the Shari'ah. Wakif is a Party who injects his property. Nazhir is a Party that receives wakaf's property from wakif to be managed and developed in accordance with its intended.PPAIW is the authorized official set by the Minister to make the Deed of Wakaf Pledge.
\end{abstract}

Keywords: Endowment and Money

* Dosen tetap fakultas Tarbiyah INZAH GENGONG KRAKSAAN 


\section{A. Pengertian Wakaf Uang}

Wakaf uang (bash wakaf/waqf al-Nuqud) telah lama dipraktikkan di berbagai Negara seperti Malaysia, Bangladesh, Mesir, Kuwait dan Negara-negara Islam di Timur Tengah lainnya. ${ }^{1}$

Di Indonesia praktik wakaf uang baru mendapat dukungan Majlis Ulama Indonesia pada tahun 2002 seiring dengan dikeluarkan Keputusan Fatwa Komisi Fatwa Majlis Ulama Indonesia tentang Wakaf Uang tanggal 28 Shafar 1423 Hijriyah/11 Mei 2002 guna menjawab Surat Direktur Pengembangan Zakat dan Wakaf Departemen Agama Nomor Dt.1.III/5/BA.03.2/2772/2002 tanggal 26 April 2002 yang berisi tentang permohonan tentang wakaf uang. ${ }^{2}$

Pada wakaf tanah, yang dapat menikmati harta wakaf tanah dan bangunan adalah rakyat yang berdomisili disekitar harta wakaf itu berada.Sementara rakyat miskin sudah sangat tersebar luas diseluruh Indonesia, sehingga dibutuhkan sumber pendanaan baru yang tidak terikat tempat dan waktu. Seiring dengan kebutuhan dana untuk pengentasan kemiskinan yang sangat besar dan lokasinya tersebar di luar daerah para wakif tersebut, timbullah pemikiran untuk berwakaf dengan uang. Uang bersifat fleksibel dan tidak mengenal batas wilayah pendistribusian. ${ }^{3}$

Dalam Fatwa Majlis Ulama Indonesia tersebut dikemukakan yang dimaksud dengan wakaf uang (bash wakaf/waqf al-Nuqud) adalah wakaf yang dilakukan seseorang, kelompok orang, lembaga atau badan hokum dalm entuk uang tunai. Termasuk kedalam pengertian uang tersebut adalah surat-surat berharga.

Selintas wakaf uang ini memang tampak seperti instrument keuangan Islam lainnya yaitu zakat, infaq, sedekah (ZIS). Padahal ada perbedaan antara instrument keuangan tersebut. Berbeda dengan wakaf tunai, ZIS bisa saja dibagi-bagi langsung dana pokoknya kepada pihak yang berhak. Sementara pada wakaf uang, uang pokoknya akan diinvestasikan terus-menerus, sehingga umat memiliki dana yang selalu

1 Abdul Ghofur Anshori, 2005. Hukum dan praktik perwakafan di Indonesia. Yogyakarta: Pilar Media. Hal. 89.

2 Rachmadi Usman, 2009. Hukum Perwakafan di Indonesia. Jakarta: Sinar Grafika. Hal. 106.

3 ibid 
ada dan insya Allah bertambah terus seiring dengan bertambahnya wakif yang beramal, baru keuntungan investasi dari pokok itulah yang akan mendanai kebutuhan rakyat miskin. Oleh karena itu, instrument wakaf tunai dapat melengkapi ZIS sebagai instrumen penggalangan dana masyarakat. ${ }^{4}$

\section{B. Dasar Hukum Wakaf Uang}

Dasar hukum wakaf uang juga bersumber pada Al-Qur'an yaitu:

1. Surah Ali Imron ayat 92:

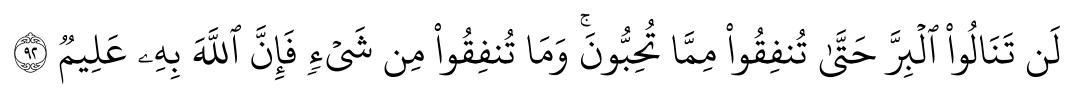

Kamu sekali-kali tidak sampai kepada kebajikan (yang sempurna), sebelum kamu menafkahkan sehahagian harta yang kamu cintai.dan apa saja yang kamu nafkahkan Maka Sesungguhnya Allah mengetahuinya.

2. Surah Al-Baqoroh ayat 262:

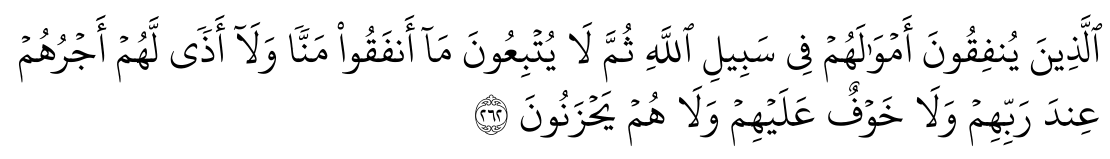

Orang-orang yang menafkahkan hartanya di jalan Allah, kemudian mereka tidak mengiringi apa yang dinafkahkannya itu dengan menyebutnyebut pemberiannya dan dengan tidak menyakiti (perasaan si penerima), mereka memperoleh pahala di sisi Tuhan mereka. tidak ada kekhawatiran terhadap mereka dan tidak (pula) mereka bersedih hati.

Dasar hukum wakaf uang juga bersumber pada Hadits yaitu:

1. Hadits riwayat Muslim, At-Tirmidzi, An-Nasa'I dan Abu Daud.

Diriwayatkan dari Abu Hurairah Ra., bahwa Rosulullah SAW bersabda: Apabila manusia meninggal dunia, terputuslah (pahala) amal perbuatannya kecuali tiga hal, yaitusedekah jariyah (wakaf), ilmu yang dimanfaatkan, atau anak sholeh yang mendoakan orang tuanya."

2. Hadits riwayat An-Nasa'i

Diriwayatkan dari Ibnu Umar ra., ia berkata, Umar ra., berkata kepada

${ }^{4}$ Ibid .Hal. 107. 
Nabi SAW., "Saya mempunyai seratus saa (tanah, kebun) di Khaibst, belum pernah saya mendapatkan harta yang lebih saya kagumi melebihi tanah itu; saya bermaksud menyedakahkannya." Nabi SAW berkata" Tahanlah pokonya dan sedekahkanlah buahnya pada sabilillah.

3. Jabir ra., berkata:

Tak ada seorang sahabat Rosul pun yang memiliki kemampuan kecuali berwakaf.

4. (HR. Bukhari-Muslim)

"Jika engkau mau, engkau tahan harta tersebut dan engkau sedekahkan hasilnya."

5. Ijma'

Disyariatkannya wakaf ini juga ditunjukkan oleh ijma', sebagaimana diisyaratkan oleh al-Imam at-Tirmidzi ketika menjelaskan hadits Umar Radhiyallaahu 'anhu tentang wakaf.Beliau berkata, "Ini adalah hadits hasan sahih.Para ulama dari kalangan para sahabat Nabi Shallallaahu 'alaihi Wasallam dan yang lainnya telah mengamalkan hadits ini.Di samping itu, kami tidak menjumpai adanya perbedaan pendapat di kalangan orang-orang yang terdahulu di antara mereka tentang dibolehkannya mewakafkan tanah dan yang lainnya."(Jami' al-Imam at-Tirmidzi).

Kebolehan wakaf uang ini, kemudian dikikuhkan atau dipertegas kembali melalui Undang-undang Nomor 41 Tahun 2004 tentang wakaf 5 . Berdasarkan Undang-undang nomor 41 Tahun 2004, benda yang dapat diwakafkan tidak hanya benda tetap, melainkan juga benda-benda bergerak, yaitu harta benda yang tak bisa habis karena dikonsumsi, meliputi uang, logam mulia, surat berharga, kendaraan, hak atas kekayaan intelektual, hak sewa, dan benda bergerak lain sesuai dengan ketentuan syariah dan peraturan perundang-undangan yang berlaku, antara lain seperti mushaf, buku, dan kitab. ${ }^{6}$

Di Indonesia, praktik wakaf uang tergolong baru, salah satu contoh wakaf uang d Indonesia adalah layanan Kesehatan Cuma-Cuma

5 Himpunan Peraturan Perundang-undangan (Undang-undang Perkawinan di Indonesia). Cetakan pertama. 2009. Wacana Intelektual. Hal .368

6 Ibid. hal. 392 
(LKC) Dompet Dhuafa Republika. Lembaga otonom Dompet Dhuafa Republika ini memberikan fasilitas permanen untuk kaum dhuafa di gedung berlantai empat, lengkap dengan operasional medis 24 jam dan mobile service. LKC adalah objek wakaf uang yang efektif, memberi cercah harapan semangat hidup sehat kaum dhuafa.Dengan adanya lembaga layanan kesehatan ini, gologan masyarakat miskin bisa memperoleh haknya tanpa perlu dibebankan oleh biaya-biaya seperti halnya rumahrumah sakit konvensional. ${ }^{7}$

\section{Unsur-unsur (Rukun) dan Syarat-syarat Wakaf Uang}

Pada dasarnya rukun dan syarat wakaf uang adalah sama dengan rukun dan syarat wakf tanah. Adapun rukun wakaf uang, yaitu:

1. Ada orang yang berwakaf (wakif);

2. Ada harta yang diwakafkan (mauquf);

3. Ada tempat ke mana diwakafkan harta itu/tujuan wakaf (mauquf alaih) atau pembentukan harta wakaf.

4. Ada akad/pernyataan wakaf (sighat) atau ikrar wakaf.

Dalam undang-undang nomor 41 Tahun 2004 terdapat tambahan unsur atau rukun wakaf, yaitu;

1. Ada orang yang meerima harta yang diwakafkan dari wakif sebagai pengelola harta.

2. Ada jangka waktu wakaf (waktu tertentu). ${ }^{8}$

Adapun yang menjadi syarat umu syahnya wakaf uang adalah:

1. Wakaf harus kekal (abadi) dan terus menerus;

2. Wakaf harus dilakukan secara tunai, tanpa digantungkan kepada akan terjadinya sesuatu peristiwa di masa akan datang, sebab pernyataan wakaf berakibat lepasnya hak milik seketika setelah wakif menyatakan berwakaf;

3. Tujuan wakaf harus jelas, maksdnya hendaklah wakaf itu disebutkan dengan terang kepada siapa yang diakafkan;

4. Wakaf merupakan hal yang harus dilaksananakan tanpa syarat boleh

7 Rachmadi Usman. Op.cit. hal. 111

8 Ibid hal. 371 
khiyar, artinya tidak boleh membatalkan atau melangsungkan wakaf yang telah dinyatakan sebab pernyataan wakaf berlaku tunai dan untuk selamanya. ${ }^{9}$

Selain rukun dan syarat, wakaf uang juga harus memperhatikan beberapa hal sebagaimana dikemukakan oleh Achmad Thohirin dalam seminar wakaf Tunai yang diselenggarakan oleh Pengurus Harian Badan Wakaf Universitas Islam Indonesia pada tanggal 13 September 2003 di Yogyakarta, yaitu;

1. Metode penghimpunan dana (fund rising), yaitu bagaimana wakaf tunaiitu dimobilisasikan. Dalam hal ini, sertifikat merupakan salah satu cara yang paling mudah, yaitu dengan nilai nominal yang berbeda-beda untuk kelompok sasaran yang berbeda. Aspek inilah yang merupakan keunggulan wakaf uang dibandingkan wakaf harta tetap lainnya, karena besarannya dapat menyesuaikan kemampuan calon wakif;

2. Pengelolaan dana yang berhasil dihimpun. Orientasi dalam mengelola dana tersebut adalah bagaimana pengelolaan tersebut mampu mamberikan hasil yang semaksimal mungkin (incomegenerating orientation). Implikasinya adalah dana-dana tersebut mesti diinvestasikan pada usaha-usaha produktif;

3. Distribusi hasil yang dapat diciptakan kepada para penerima manfaat (beneficiaries). Dalam mendistribusikan hasil ini yang perlu diperhatikan adalah tujuan/orientasi dari distribusi tersebut, yang dapat berupa penyantunan (charity), pemberdayaan (empowerment), investasi sumber daya insani (human investment), maupun investasi infrastruktur (infrastructure investment). Disamping itu, hasil yang diperoleh tersebut juga perlu sebagian proxy tertentu dialokasikan untuk menambah besaran nilai awal wakaf uang dengan pertimbangan pokok untuk mengantisipasi penurunan nilai wakaf uang dan meningkatkan kapasitas modal awal tersebut. ${ }^{10}$

9 Rachmadi Usman. Op.cit. hal. 112

${ }^{10}$ Rachmadi Usman. Op.cit. hal. 113 


\section{Manfaat dan Tujuan Wakaf Uang}

Dibandingkan dengan wakaf tanah dan benda lainnya, peruntukan wakaf uang jauh lebih fleksibelitas (keluwesan) dan meiliki kemaslahatan lebih besar yang tidak dimiliki oleh benda lainnya.

Selain itu ada 4 (empat) manfaat sekaligus keunggulan wakaf uang dibandingkan dengan wakaf benda tetap yang lain, yaitu;

1. Wakaf uang jumlahnya bisa bervariasi, seseorang yang memiliki dana terbatas sudah bisa mulai memberikan dana wakafnya tanpa harus mengganggu menjadi tuan tanah terlebih dahulu;

2. Melalui wakaf uang, asset-aset wakaf yang berupa tanah-tanah kosong bisa mulai dimanfaatkan dengan pembangunan gedung atau diolah untuk lahan pertanian;

3. Dana wakaf uang juga bisa membantu sebagian lembaga-lembaga pendidikan Islam yang cash flow- nya ternyata kembang - kempis dan menggaji civitas akademik alakadarnya;

4. Padagilirannya, umat Islam dapat lebih mandiridalam mengembangkan dunia pendidikan tanpa harus terlalu tergantung pada anggaran pendidikan negra yang memang semakin lama terbatas.

\section{Adapaun tujuan wakaf uang adalah;}

1. Melengkapi perbankan Islam dengan produk wakaf uang yang berupa suatu sertifikat berdenominasi tertentu yang diberikan kepada para wakif sebagai bukti keikutsertaan;

2. Membantu penggalangan tabungan social melalui sertifikat wakaf Tunai yang dapat diatasnamakan orang-orang tercinta baik yang masih hidup maupun yang telah meninggal, sehingga dapat memperkuat integrasi kekeluargaan di antara uma;

3. Menugkatkan investasi social dan mentransformasikan tabungan social menjadi modal soasial dan membantu pengembangan pasar modal social;

4. Menciptakan kesadaran orang kaya terhadap tanggung jawab social mereka terhadap masyarakat sekitarnya, sehingga keamanan dan kedamaian social dapat tercapai. ${ }^{11}$

\footnotetext{
${ }^{11}$ Rachmadi Usman. Op.cit. hal. 115
} 


\section{E. Tata Cara dan Pengelolaan Wakaf Uang}

Sebagaimana dikemukakan di atas, bahwa Undang - undang Nomor 41 tahun 2004 telah memperluas benda yang dapat diwakafkan oleh wakif, yang secara umum terbatas kepada benda tidak bergerak atau benda tetap seperti tanah dan bangunan,kini bergerak lainnya dapat diwakafkan. Wakaf benda bergerak berupa uang diatur secara khusus dalam pasal 28 sampai dengan pasal 31 Undang - undang nomor 41 Tahun 2004', yang kemudian dijabarkan lebih lanjut dalam pasal 22 sapai dengan pasal 27 dan pasal 43 Peraturan pemerintah Nomor 42 tahhun 2006 tentang Pelaksanaan Undang-undang Nomor 41 Tahun 2004 tentang Wakaf. ${ }^{13}$

Dikemukakan bahwa wakif (pihak yang mewakafkan harta bendanya) dapat mewakafkan benda bergerak berupa uang (wakaf uang), yang dilakukan melaui Lembaga Keuangan Syariah yang di tunjuk oleh menteri yang bertanggung jawab di bidang agama sebagai Lembaga Keuangan Syariah Penerima Wakaf Uang (LKS-PWU) yang ditunjuk tersebut atas dasar saran dan pertimbangan dari Badan Wakaf Indonesia (BWI) setelah mempertimbangkan saran instansi terkait.

Wakaf uang yang dapat diwakafkan tersebut dipersyaratkan harus mata uang rupiah, namun bila masih dalam mata uang asing, maka harus dikonversi terlebih dahul ke dalam rupiah.

Wakif yang akan mewakafkan uangnya tersebut diwajibkan untuk;

1. Hadir di Lembaga Keuangan Syariah Penerima Wakaf (LKS-PWU) untuk menyatakan kehendakwakaf uangnya. Apabila wakif tidak bisa hadir, maka wakif dapat menunjuk wakil atau kuasanya.

2. Menjelaskan kepemilikan dan asal usulyang akan diwakafkan dalam rangka untuk menjamin benda wakaf berasal dari sumber halal, tidak bertentangan dengan syariah dan peraturan perundang-undangan, misalnya menhindari kemungkinan praktik pencucian uang melalui wakaf;

3. Menyetorkan secara tunai sejumlah uang ke LKS-PWU;

4. Mengisi formulir pernyataan kehendak wakif yang berfungsi sebagai Akta Ikrar Wakaf (AIW).

${ }^{12}$ Himpunan Peraturan Perundang-undangan (Undang-undang Perkawinan di Indonesia). Cetakan pertama. 2009. Wacana Intelektual. Hal .377-378

${ }^{13}$ Departemen Agama.2006. Peraturan Peundangan Perwakafan.Jakarta: Direktorat Jendaral Bimbingan Masyarakat Islam. 
Wakaf $^{14}$ uang ini dilaksanakan oleh wakif dengan pernyataan kehendak (ikrar wakaf) wakif yang dilakukan secara tertulis kepada nazhir di hadapan Pejabat Pembuat Ikrar Wakaf (PPAIW) yang selanjutnya nazhir menyerahkan AIW tersebut kepada LKS-PWU.

Apabila ikrar wakaf sudah dilaksanakan oleh wakif, kepadanya diberikan Sertifikat Wakaf Uang (SWU) yang diterbitkan dan disampaikan oleh LKS-PWU bersangkutan kepada wakif dan nazhir sebagai bukti penyerahan harta benda wakaf.Penempatan uang wakaf melalui LKS-PWU dimaksudkan sebagai titilan (wadiah).Nazhir dapat mengelolanya dengan memperhatikan kehendak wakif serta rekomendasi manager investasi (bila ada).

Adapun keterangan yang wajib dimuat dalam Sertifikat Wakaf Uang sekurang-kurangnya memuat mengenai;

a. Nama LKS Penenrima Wakaf Uang;

b. Nama wakif;

c. Alamat wakif;

d. Jumlah wakaf uang, yaitu nila nominal wakaf uang yang harus dicantumkan dalam sertifikat wakaf uang dan disesuaikan jumlah minimum yang berlaku pada LKS-PWu bersangkutan;

e. Peruntukan wakaf;

f. Jangka waktu wakaf,yaitu untuk waktu terbatas (muaqqat) atau tidak terbatas (muabbad).

g. Nama nazhir yang dipilih;

h. Alamat Nazhir yang diplih;

i. Tempat dan tanggal penerbitan Sertifikat Uang;

SelanjutnyaLKS-PWUbersangkutan atas namanazhir mendaftarkan wakaf uang tersebut kepada mentri yang bertanggung jawab di bidang agama selambat-lambatnya 7 (hari) kerja sejak diterbitkannya Sertifikat Wakaf Uang.

${ }^{14}$ Wakaf adalah perbuatan hukum wakif untuk memisahkan dan/atau menyerahkan sebagian harta benda miliknya untuk dimanfaatkan selamanya atau untuk jangka waktu tertentu sesuai dengan kepentinganya guna keperluan ibadah dan/atau kesejahteraan umum menurut syari'ah. Wakif adalah Pihak yang mewakafkan harta benda miliknya. Nazhir adalah Pihak yang menerima harta benda wakaf dari wakif untuk dikelola dan dikembangkan sesuai dengan peruntukannya. PPAIW adalah pejabat yang berwenang yang ditetapkan oleh Menteri untuk mmembuat Akta Ikrar Wakaf. Himpunan Peraturan Perundang-undangan (Undang-undang Perkawinan di Indonesia). Cetakan pertama. 2009. Wacana Intelektual. Hal .369. 
Apabila wakaf tunai dapat dilaksanakan dengan baik, maka akan terbuka peluang bagi penciptaan investasi di bidang keagamaan, pendidikan, dan pelayanan social. Tabungan dari anggota masyarakat yang berpenghasilantinggi dapat dimanfaatkan melalui penukaran Sertifikat Wakaf Tunai (SWT), sedangkan hasil dari pengolahan wakaf tunai itu dibelanjakan untuk berbagai tujuan, di antaranya untuk pemeliharaan harta wakaf itu sendiri serta pengeluaran-pengeluaran lannya. Dengan penerbitan SWTakan membuka peluang untuk penggalangan dana menjadi sangat luas diabndingkan dengan wakaf biasa. Disamping itu, SWT dapat dibuat dalam berbagai macam pecahan yang disesuaikan dengan kemampuan masyarakat muslim yang ingin melaksanakan wakaf tunai. Waaf tunai di harapkan dapat menciptakan kesadaran orang kaya terhadap tanggung jawab social mereka terhadap masayarakat sekitarnya. ${ }^{15}$

Pada wakaf uang, dana wakaf yang diperoleh dari para wakif akan dikelola oleh nazhir (pengelola wakaf) yang dalam hal ini bertindak sebagi manajemen investasi. Para wakif tersebut mensyaratkan kemana alokasi pendistribusian keuntungan investasi wakaf nantinya.Kemudian dana wakaf tersebut dikelola dan diinvestasikan sebagian pada instrument keuangan syari'ah, sebagian lagi diinvestasikan langsung ke berbagai badan usaha yang bergerak sesuai syari'ah, dapat juga diinvestasikan untuk mendanai pendirian badan usaha baru. Portofolio investasi lainnya adalah menyalurkan dana melalui kredit mikro ke sector-sektor yang mampu mengurangi pengangguran dan menciptakan calon-calon wirausaha baru. ${ }^{16}$

\section{F. Penutup}

Keuntungan dari investasi (wakaf uang) di atas siap didistribusikan kepada rakyat miskin melalui pengadaan dana kesehatan, pendidikan, rehabilitasi keluarga, bantuan untuk bencana alam, perbaikan infrastruktur dan sebagainya yang persentasenya sesuai dengan permintaan wakif.

${ }^{15}$ Abdul Manan. 2006. Aneka Masalah Hukum Perdata Islam di Indonesia. Jakarta: Kencana Prenada Media Group.

${ }^{16}$ Rachmadi Usman. Op.cit. hal. 117 
Adapun uang pokoknya akan diinvestasikan terus-menerus sehingga umat memiliki dana yang selalu ada dan insya Allah bertambah terus seiring dengan bertambahnya jumlah wakif. Yang beramal. ${ }^{17}$

${ }^{17}$ Abdul Ghofur Anshori.2005.Hukum dan Praktik Perwakafandi di Indonesia. Yogyakarta: Pilar Media. Hal 104 


\section{Daftar Pustaka}

Abdul Ghofur Anshori, 2005. Hukum dan praktik perwakafan di Indonesia.Yogyakarta: Pilar Media. Hal. 89.

Rachmadi Usman, 2009. Hukum Perwakafan di Indonesia. Jakarta: Sinar Grafika. Hal. 106.

Himpunan Peraturan Perundang-undangan (Undang-undang Perkawinan di Indonesia). Cetakan pertama. 2009. Wacana Intelektual. Hal .368

Himpunan Peraturan Perundang-undangan (Undang-undang Perkawinan di Indonesia). Cetakan pertama. 2009. Wacana Intelektual. Hal .377-378

Departemen Agama.2006. Peraturan Peundangan Perwakafan. Jakarta: Direktorat Jendaral Bimbingan Masyarakat Islam

Abdul Manan. 2006. Aneka Masalah Hukum Perdata Islam di Indonesia. Jakarta: Kencana Prenada Media Group.

Rachmadi Usman. Op.cit. hal. 117

Abdul Ghofur Anshori.2005.Hukum dan Praktik Perwakafandi di Indonesia.Yogyakarta: Pilar Media. Hal 104 